\title{
УДК 7.097:654.197
}

DOI: $10.31866 / 2617-2674.2 .2018 .151788$

\author{
Наталія Цімох, \\ ORCID: https://orcid.org/0000-0002-6147-3341 \\ доиент кафедри тележурналістики \\ та майстерності актора, \\ Київський начіональний університет \\ культури і мистецтв, \\ заслужений працівник культури України, \\ Київ, Украӥна \\ e-mail:tsimoh.n@gmail.com
}

Анастасія Сорока, ORCID: https://orcid.org/0000-0001-9883-1686 магістрант кафедри тележурналістики та майстерності актора, Київський національний університет культури і мистецтв, Київ, Україна e-mail:belobokaa19@gmail.com

\section{ОСОБЛИВОСТІ ПРИЙОМІВ ІНФОТЕЙНМЕНТУ}

Мета дослідження полягає у 3'ясуванні особливостей витоків, історичної еволюції сучасних тенденцій у розвитку інфотейнменту. Для досягнення вказаної мети доречним видається проаналізувати літературу та джерела, пов'язані з появою поняття «інфотейнмент». Також автори ставили на меті проаналізувати класифікацію прийомів інфотейнменту та виявити зовнішні і внутрішні зв'язки між ними, дослідити застосування прийомів інфотейнменту та охарактеризувати перспективи їх розвиток на українському телебаченні. Методологія дослідження. Запропонована публікація передбачає використання певного комплексу методів дослідження. Бібліографічноописовий метод дав змогу зрозуміти, наскільки інфотейнмент $є$ дослідженим й актуальним явищем сьогодення. Метод спостереження дав можливість виявити передумови появи інфотейнменту та процес його становлення й розвитку. За допомогою аналітичного методу висвітлено характеристику сучасного етапу функціонування інформаційно-публіцистичного сегменту на українському телебаченні. Наукова новизна отриманих результатів полягає в тому, що вперше детально проаналізовано особливості реалізації інфотейнменту на сучасному українському інформаційно-публіцистичному телебаченні, здійснено структурний аналіз ознак, проявів і прийомів інфотейнменту, теоретично обгрунтувано процес трансформації інформаційно-аналітичного сегменту ТБ в інформаційно-публіцистичний. Висновки. В процесі дослідження було виявлено причини, які сприяли появі та становленню особливостей прийомів інфотейнменту. На основі розгляду історіографії та джерельної бази було з'ясовано, що проблема інфотейнменту в Україні є малодослідженою й досі комплексно не розглядалася. Аналіз даної теми дає можливість стверджувати, що інфотейнмент - спосіб подачі новин в розважальній формі, який досягається за допомогою різних прийомів. Цей аспект є корисним для кожного журналіста, оскільки 
використання спеціальних технологій дає можливість впливати не на розум, а на емоційний стан глядача.

Ключові слова: інфотейнмент, прийоми, украӥнське телебачення, зображальновиражальні засоби.

Наталья Цимох, дочент кафедры тележурналистики и актерского мастерства, Киевский национальный университет культуры и искусств, заслуженный работник культуры Украины, Киев, Украина

Анастасия Сорока, магистрант кафедры тележурналистики и актерского мастерства, Киевский национальный университет культуры и искусств, Киев, Украина

Особенности приемов инфотейнмента

Цель исследования состоит в определении особенности истоков, исторической эволюции современных тенденций в развитии инфотейнмента. Для достижения указанной цели необходимым кажется проанализировать литературу и источники, связанные с появлением понятия «инфотейнмент». Проанализировать классификацию приемов инфотейнмента и определить внешние и внутренние связи между ними. Также авторы ставили цель исследовать применение приемов инфотейнмента, и охарактеризовать перспективы их развития на украинском телевидении. Методология исследования. Предложенная публикация предусматривает использование определенного комплекса методов исследования. Библиографическойописательный метод позволил понять, насколько инфотейнмент исследован и есть актуальным явлением современности. Метод наблюдения сформировал источники появления инфотейнмента и процесс его становления и развития. С помощью аналитического метода охарактерезован современный этап функционирования информационно-публицистического сегмента на украинском телевидении. Научная новизна полученных результатов заключается в том, что впервые подробно проанализированы особенности реализации инфотейнмента на современном украинском информационно-публицистическом телевидении, осуществлено структурный анализ признаков, проявлений и приемов инфотейнмента, теоретически обосновано процесс трансформации информационно-аналитического сегмента ТВ в информационно-публицистический. Выводы. В процессе исследования выяснены причины, которые способствовали появлению и становлению особенностей приемов инфотейнмента. На основе рассмотрения историографиии и источниковой базы выяснилось, что проблема инфотейнмента в Украине является малоисследованной до сих пор комплексно не рассматривалась. Анализ данной темы дает возможность утверждать, что инфотейнмент - способ подачи новостей в развлекательной форме, который достигается с помощью различных приемов. Этот аспект является полезным для каждого журналиста, поскольку использование специальных технологий позволяет воздействовать не на разум, а эмоциональное состояние зрителя.

Ключевые слова: инфотейнмент, приемы, украинское телевидение, изобразительно-выразительные средства.

Nataliia Tsimokh, Associate Professor of the Department of Television Journalism and Acting, Kyiv National University of Culture and Arts, Honored Worker of Culture in Ukraine, Kyiv, Ukraine

Anastasiia Soroka, Master Student, Department of Journalism and Acting, Kyiv National University of Culture and Arts, Kyiv, Ukraine

Features of receptions infotehnament

Purpose of the study is to find out the features of the origins, historical evolution of modern trends in the development of infotinment. Analyze literature and sources related to the 
emergence of the concept of "infotehnament". Analyze the classification of infotment techniques and identify the external and internal links between them. Explore the use of infotehnology techniques, and to describe the prospects for their development on Ukrainian television. Research methodology. The proposed publication implies the use of a specific set of research methods. The bibliographic descriptive method made it possible to understand how infotehnum is an investigated and actual phenomenon of the present. The method of observation made it possible to identify the preconditions for the emergence of infotment and the process of its formation and development. Using the analytical method, the characteristics of the modern stage of the functioning of the informational and journalistic segment on the Ukrainian television are highlighted. Scientific novelty the obtained results is that for the first time the details of the implementation of infotehnation on the modern Ukrainian informational and journalistic television have been analyzed in detail, the structure analysis of signs, manifestations and techniques of infotehnum has been carried out, the process of transformation of the information-analytical segment of TV into informational and journalistic is theoretically substantiated. Conclusions. In the course of the study, there were identified causes that contributed to the emergence and development of features of infotment techniques. On the basis of consideration of historiography and source base, it was found that the problem of infotment in Ukraine is poorly understood and has not yet been fully addressed. Analysis of this topic makes it possible to argue that infotehnament - a way to feed news in an entertaining form, which is achieved through various techniques. This aspect is useful for every journalist, since the use of special technologies makes it possible to influence not the mind but the emotional state of the viewer.

Key words: infotehnament, receptions, Ukrainian television, figurative-expressive means.

Мета дослідження. Автори статті намагаються 3'ясувати особливості витоків та простежити історичну еволюцію сучасних тенденцій у розвитку інфотейнменту. Для досягнення цього завдання був проаналізований пласт вузькоспеціальної літератури та джерел, пов'язаних 3 появою поняття «інфотейнмент». Також слід проаналізувати класифікацію прийомів інфотейнменту та виявити зовнішні і внутрішні зв'язки між ними, дослідити застосування прийомів інфотейнменту та охарактеризувати перспективи їх розвитку на українському телебаченні.

Постановка проблеми. Інфотейнмент, як явище відносно молоде на світовому телебаченні, в більшій мірі співвідноситься з поняттям «формат», так як має на увазі наявність певної методики подачі інформації. Дана методика формується на базі стилістичних прийомів, характерних саме для інфотейнменту. А. Г. Качкаева (2010, с.50-56) зазначає, що «якщо все-таки залишити «формат» - індустрії, якій в його категоріях легше домовлятися всередині себе і з зовнішнім, міжнародним середовищем, а жанр зберегти для вічності, то протиріччя практично зникають». «Формат» являє собою спосіб «конвеєрного» виробництва телевізійного продукту, він має на увазі деяку його шаблонність, проте описана і чітка методика виробництва дозволяє оперативно формувати контент заданої якості для певної аудиторії. На користь віднесення інфотейнменту саме до «формату» висловлюється i С. К. Степянян (2006, с.42-43). Феномен інфотейнменту залишається не до кінця вивченим дослідниками журналістики. 3 цієї причини творцям телепрограм не завжди вдається успішно і ефективно скористатися всіма прийомами даного методу подачі інформації. Тому було прийнято рішення про необхідність удосконалити 
подальші дослідження прийомів інфотейнменту, їх використання на сучасному новинному телебаченні, виявити результативність даних засобів та дослідити вплив розглянутого нами феномена на аудиторію.

Аналіз останніх досліджень і публікацій. Перший розгорнутий аналіз явища «Інфотейнмент» відноситься до кінця минулого століття (Нік Постман «Розважаючись до смерті» (Amusing ourselves to death. New York, 1985); Майкл Д. Мюррей «Енциклопедія теленовин» (Encyclopedia of television news)) (1985, с.42).

У книзі Н. Постмана «Розважаючись до смерті» інфотейнмент постає не просто як спосіб передачі навколишньої дійсності, але як відображення певного світогляду через мас-медіа.

Відзначимо, що у поняття «інфотейнмент» немає точного наукового визначення. Протягом 1990-х pp. теоретики мас-медіа активно вивчали вказаний феномен. Кожен дослідник розробляв власну, вузьку інтерпретацію цього явища в залежності від своєї сфери дослідження.

Термін «інфотейнмент» з'явився в роботах вітчизняних дослідників в кінці 1990 - початку $2000 \mathrm{pp}$. Перше визначення цього явища було опубліковано в російсько-англійському вокабулярі Л. М. Землянова $(1999$, c.167): інфотейнмент «висловлює прагнення продюсерів подавати новини в формі розважальних передач або 3 відтінком розважальності». Відзначимо, що спочатку метод інфотейнменту сприймався як негативне явище, яке веде до занепаду освіченості аудиторії. Наприклад, такі дослідники, як В. Л. Цвік, Б. Н. Лозовський, Л. Мікос (2000， с.116)， вважають， що через використання методу інфотейнменту всі сфери життя перетворюються в придаток шоубізнесу і не передають істинної суті події або явища. Ця традиція бере початок ще в медіакритиці Н. Постмана. Однак останнім часом можна зустріти думку, що інфотейнмент - це, в першу чергу, форма, в яку огортається інформація, щоб полегшити іiї розуміння для максимально великої кількості адресатів, як того вимагає розвиток ЗМІ.

Виклад основного матеріалу. Наше знайомство 3 теоретичною літературою виявило той факт, що існує безліч різних прийомів інфотейнменту, але чітко регламентованої, єдиної класифікації цих прийомів, що зустрічаються на телебаченні, немає.

На наш погляд, всі прийоми інфотейнменту, використовувані в інформаційних програмах можна розділити на наступні групи:

1. Структурно-композиційні - прийоми, за допомогою 3 яких сюжет виходить цікавим і креативним, спосіб вираження задуму автора;

2. Змістовні - позначають тему для сюжету, його місце в випуску, спосіб інтерпретації інформації;

3. Мовні - включають в себе використання різноманітних синтаксичних і лексичних прийомів виразності: тропів, фігур, мовної гри. Також до цієї групи нам здається доцільним включити i невербальні елементи: міміку, жестикуляцію, інтонацію і тембр мови журналістів. На наш погляд, лексичні та паралінгвістичні прийоми правильніше розглядати як єдине ціле, так як невербальні елементи, що використовуються в процесі передачі смислової інформації разом з вербальними засобами, i, отже, ці елементи $є$ ланками єдиного акту передачі мовного повідомлення. 
Розглянемо більш докладно кожну групу прийомів інфотейнменту.

До основних структурно-композиційних прийомів ми віднесемо наступне: музичне та візуальне оформлення, а також художній монтаж, лайфи і люфти, тобто ті засоби, які надають відео сюжету виразність.

Для інфотейнменту використання музичних заставок і композицій є дуже важливим і популярним прийомом. Сама по собі музика не несе смислового навантаження, але сприяє комплексному сприйняттю інформації. П. А. Гагаріна вважає, що музику в телеефірі використовують для підтримки контакту з аудиторією, а саме для:

- «підігрівання» глядацького інтересу;

- розстановки смислових акцентів;

- створення емоційної атмосфери;

- передачі ефекту присутності (особливо часто застосовується в прямому ефірі, в репортажах).

Звичайно, так само варто відзначити і музичні заставки, які виконують організуючу функцію і $€$ «обличчям» кожної телепрограми (Гагаріна, 2010, с.32-34).

Візуальне оформлення - це спосіб наочного зображення інформації, яку кореспонденти i ведучі підносять глядачам. Телеканали використовують прийоми візуалізації, перш за все для того, щоб інформація виглядала більш доступною, зручною і гранично зрозумілою кожному глядачеві.

До цієї категорії ми відносимо наступні елементи візуального оформлення в новинних випусках:

1. Інфографіка - використовується для наочної демонстрації чисел, статистичних відомостей у вигляді діаграм, графіків і т.п. Застосовується для того, щоб цифрові дані легше сприймалися і засвоювалися глядачем;

2. Фотографії, схеми, карти і скріншоти, комп'ютерна анімація - часто використовуються журналістами в якості відеоряду для закадрового тексту. У час стрімкого розвитку комп'ютерних технологій демонстрація скріншотів (точних зображень на моніторі комп'ютера) з соціальних мереж політичних діячів та інших відомих особистостей особливо викликає інтерес і довіру сучасного глядача.

Для програм в стилі інфотейнмент візуальне оформлення дуже важливе, так як це «легкий» спосіб представлення самих різних відомостей, який допомагає навіть складні або нудні для сприйняття на слух дані зробити більш простими i зрозумілими, що сприяє швидкому засвоєнню інформації аудиторією.

«Монтаж» в перекладі з французької означає «складання, конструювання». За допомогою монтажу журналіст може створювати абсолютно різні за змістом інформаційні блоки. Як засіб виразності монтаж використовується для того, «щоб викликати у глядача відповідні емоції, включити ланцюг асоціацій, захопити темпом і ритмом дії» (Познин, 2004, с.16-18).

Ми виділили основні прийоми художнього монтажу, які активно застосовуються при створенні телепередач в стилі інфотейнмент:

1. Різні відеовставки - даний прийом включає в себе використання відео з архівів, художніх і документальних фільмів, відеокліпів, а також аматорські відео 3 «місця подій»; 
2. Прийом зміни плану - найчастіше використовується для передачі емоцій і почуттів героїв програми, або для акцентування уваги на конкретних деталях;

3. Прийом асоціативного зв'язку - має на увазі використання «Аналогій і контрастів, подібностей i відмінностей, які дають можливість активного емоційного впливу на глядача, створення надзвичайних ефектів, що впливають на глядацьку уяву. Багато матеріалу для аналогій і контрастів дають кадри природних явищ або тварин, які надають матеріалу метафоричне звучання» (Познин, 2004, с.16-18);

4. Прийом рефрену - являє собою неодноразове повторення будь-якої деталі. Тим самим демонструється ऑї важливість в контексті сюжету i акцентується надмірною глядацькою увагою на визначених символах.

Багато медіадослідників вважають, що глядач хоче бачити реальне життя без прикрас. Н. В. Звєрєва (2008, с.200) пише з цього приводу: «Глядачеві не потрібні журналістські коментарі. Особливо цікаво йому як би підглядати за людьми, які опинилися в складній ситуації: як вони реагують на проблему, плачуть або, навпаки, замикаються в собі» Для того, щоб показати глядачам життя таким, яким воно є, кореспонденти використовують в своїх сюжетах лайфи i люфти - прийоми, які прийшли в новинну журналістику 3 документалістики. «Лайф - це жива картинка 3 живим звуком і коментарем, що має принципове смислове значення» - таке визначення дає Н. В. Звєрєва (2008, с.196-203) одному з яскравих елементів інфотейнменту.

Змістовні прийоми позначають причину вибору тематичного спектра, способів трактування подій кореспондентом, а також способи подачі інформації. До цієї групи прийомів відноситься: тема як ядро змісту, сенсаційність, виступ журналіста як актора.

До тематичних прийомів відносяться і трешеві елементи, які прийшли в інформаційне мовлення 3 документалістики. Ми відзначаємо, що трешестетика може проявлятися i на структурно-композиційному рівні, але в нашому дослідженні треш на рівні теми представляє більший інтерес.

Трешем в кіно називали неякісний, поганий фільм 3 низьким бюджетом. Вперше треш стали використовувати в ЗМІ на початку 19 століття. Треш (trash) - в перекладі 3 англійської мови «дурниця», «погань», «смітник». «Колись цим розмовним словом, в тому, числі обзивали бульварну пресу типу «New York sun», яка ще в 1833 році спеціалізувалася на описі життя злодіїв, повій, насильстві і вже тоді викликала страшний гнів громадськості» (Postman, 1985, c.78).

У 20 столітті поняття «треш» увійшло в побут видавців, стало означати певний тип масової літератури, який характеризувався великою кількістю штампів, банальних ідей і неоригінальних сюжетних ліній.

На телебачення треш прийшов з США. У 1985 р американські журналісти розробили так звану «філософію» трешу: робити події реального життя якомога більш драматичними й цікавими (Postman, 1985, с.189).

Серед головних характеристик телевізійного треш-продукту дослідники виділяють наступні:

- зміст визначає культура повсякденності. Реальність досліджується не в рамках системи «людина - буття», а в рамках системи «людина - побут». При 
цьому не важливо, хто є документальним героєм - знаменитість, обиватель або історична особистість;

- звернення до тілесного, до проблем і потреб «низу»;

- домінанта естетики потворного;

- в основному в ефір потрапляють матеріали, що відповідають принципам сенсаційності та екстремальності, патології і збоченості.

Коротко про треш в журналістиці можна сказати, що програми такого типу апелюють такими темами як смерть, насильство, жорстокість, катастрофи, приватне і сексуальне життя. Річард Харріс (2002, с.101) пише, що «така шокуюча інформація допомагає тимчасово позбутися глядачеві від почуття страху i невизначеності», «відбувається свого роду психотерапевтична десенситизація, тобто зниження чутливості до факторів, що породжує страх».

Сенсаційність - найважливіша характеристика стилю інфотейнмент. Під сенсацією мається на увазі ексклюзивна, інтригуюча інформація, яка часто буває і шокуючою. Л.А. Васильєва (2003, с.97) пише, що «Сенсаційність присутня в будь-якій, самій повсякденній темі. Сенсаційна новина повинна бути винятковою, описувати виняткові факти». Слід зазначити i «брудні» сенсації, які частіше всього можна побачити в трешевих програмах.

Дослідники пишуть, що найбільшою популярністю серед аудиторії користуються сюжети, яким притаманний наліт (Васильєва, 2003, с.124):

- сенсаційності, яка визначається факторами несподіванки (катастрофи, стихійні лиха, сенсації в політиці і спорті), незвичайності;

- парадоксальності.

Щодо виконання журналістом функції актора, то в цьому сенсі стиль інфотейнмент має на увазі багаторазове збільшення ролі i значущості кореспондента. Дуже часто можна спостерігати, як журналіст стає безпосереднім учасником подій, що відбуваються, тим самим налагоджуючи контакт 3 аудиторією, культивуючи відчуття присутності. Нерідко на екрані можна побачити «героїзацію» репортера, в очах глядачів він постає як позитивний персонаж з відповідними якостями. Він працює на місці подій, проводить власне розслідування, розмовляє зі свідками, робить висновки і представляє аудиторії повну картину подій, яка може викликати резонанс в суспільстві. Таким чином, журналіст виконує етично важливу місію, долаючи безліч труднощів і небезпек на своєму шляху.

В якості складової прийому «журналіст як актор» розглядається і стендап. Стендап (англ. Stand-up - виконаний стоячи) - монолог репортера в кадрі на місці події, є постановочним епізодом при зйомці (Новикова, 2008, с.23). Стендап - це авторський підпис під репортажем, але поява репортера в кадрі має бути чимось обгрунтовано: немає відеоряду для ілюстрації розповіді. Це може статися, якщо немає можливості відзняти необхідний матеріал, так як зйомка не дозволена; необхідно логічно перейти від однієї частини матеріалу до іншої. Дозволяє розбити репортаж на смислові частини; кореспондент в незвичайній обстановці; журналіст робить акцент на який-небудь предмет у кадрі (Новикова, 2008, с.31).

До мовних прийомів групи відносяться засоби мовної виразності, які 
в телевізійній практиці активно використовують журналісти. Нижче розглянемо мовні прийоми, які найчастіше зустрічаються, які властиві стилю інфотейнмент: мовну гру, експресивність, іронію, саспенс і драматизацію.

Мовна гра - це «специфічне вживання мовних одиниць». У науку термін ввела О. Ф. Майдурова. Інші медіадослідники пишуть, що це «явище, коли той, що говорить «грає» 3 формою мови, коли вільне ставлення до форми мови отримує естетичне завдання, нехай навіть саме скромне» (Майдурова, 2011, с.23). До мовної гри відносяться різні жарти, каламбури. На сучасному телебаченні мовна гра - одна $з$ найбільш поширених виразних засобів.

Е. М. Драгун $(2015$, с.131) вважає, що мовна гра «сприяє більш успішному прояву дотепності журналіста, що підвищує його авторитет в очах аудиторії».

Експресивність - емоційно забарвлює мову кореспондента, допомагає висловити емоції. Вживання емоційно забарвлених одиниць сприяє реалізації комунікативної функції мови.

Іронія є прийомом експресії, але, вважається, що даний засіб варто виділити як окремий елемент, так як він являе собою потужне «знаряддя» для залучення глядацької уваги.

Саспенс (англ. Suspense - занепокоєння, тривога очікування): як пояснює енциклопедичний словник, цей термін означає «сюжетну напругу». Визначення прийшло 3 кінематографа. У тележурналістиці саспенс також $\epsilon$ ефект напруженого очікування. Прийом саспенсу найчастіше використовується в анонсі сюжетів або нових «поворотів» в обговоренні в різних телепередачах розважального характеру. Саспенс застосовується для створення інтриги з метою підтримання глядацького інтересу і для того, щоб змусити додивитися програму до кінця, щоб дізнатися всі подробиці.

Драматизація - «фундаментальна властивість телевізійного тексту, яка проявляється як в випадково, так і навмисному наповненні образів змістом, безпосередньо не закладеному в дійсності» (Драгун, 2015, с.84). Слід відзначити, що драматизація може проявлятися i на змістовному, i на структурно-композиційному рівнях. Основна функція драматизації - викликати у глядача широкий діапазон емоцій типу співпереживання, жалю, співчуття.

Висновки. Прийоми інфотейнменту в інформаційних програмах $\epsilon$ системою, що включає в себе як структурно-композиційні (використання фрагментів з фільмів, кадрів з архіву, мелодій, комп'ютерної графіки та анімації, різні прийоми художнього монтажу, лайфи тощо), змістовні («тема як ядро змісту», сенсаційність, «журналіст як актор»), так і мовні прийоми (мовна гра, експресивність, іронія, саспенс, драматизація). Дані елементи забезпечують динамічність і креативність сюжетів, емоційно впливають на аудиторію, тим самим привертаючи увагу глядачів i виводячи їх з фонового перегляду. Всі групи прийомів насичують інформацію засобами виразності, володіючи творчим, розважальним потенціалом, покликані збагачувати інформацію виразними засобами. Але в той же час слід зазначити, що активне впровадження прийомів інфотейнменту в інформаційне мовлення знижує роль інформаційної складової телевізійного продукту. 


\section{Список посилань}

Васильева, Л.А., 2003. Делаем новости!. Москва: Аспект Пресс.

Васильева, Т.В., Осинский, В.Г. и Петров, Г.Н. 2003. Радиотелевизионная журналистика в системе професиональных координат. Ч. 2. Санкт Петербург.

Гагарина, П.А., 2010. Приемы звукового оформления телеперадач. [онлайн] Доступно: $<$ http://jour.vsu ru/edition/journals/accents/2010/accents_1-2_2010.pdf $>$ [Дата обращения 21 сентября 2018]

Драгун, Е.М., 2015. Инфотейнмент как явление современной медиакультуры. Кандидат наук. Московский государственный университет имени М.В. Ломоносова.

Зверева, Н.В., 2008. Школа регионального журналиста. Москва: Аспект Пресс.

Землянова, Л.М., 1999. Зарубежная коммуникативистика в преддверии информационного общества: толковый словарь терминов и концепций. Москва.

Земская, Е.А., Китайгородская, М.А. и Розанова, Н.Н., 1983. Языковая игра. В: Русская разговорная речь. Москва.

Качкаева, А.Г., 2010. Жанры и форматы современного телевидения. Последствия трансформации. Вестник Московского университета. Серия 10. Журналистика, 10 (44), c.50.

Майдурова, О.Ф., 2011. Информачионные жанры в региональных новостных телепрограммах: актуальные тенденции. Санкт Петербург, с.23.

Новикова, А.А., 2008. Современные телевизионные зрелища: истоки, формы и методы воздействия. Москва.

Познин, В.Ф., 2004. Основы монтажа изображения. Санкт Петербург.

Степанян, С.К., 2006. Формат телепрограммы как рыночный товар. Журналистика и медиарынок, 4, с.42-43.

Стилистический энциклопедический словарь русского языка, 2018. [online] Доступно: $<$ http://stylistics.academic ru/271> [Дата обращения 15 июля 2018]

Харрис, Р., 2002. Психология массовых коммуникащий. Санкт Петербург: ПРАЙМЕВРОЗНАК.

Цвик, В.Л., 2000. Введение в журналистику. 2-ге изд. Москва: Изд-во МНЭПУ.

Postman, N., 1985. Amusing Ourselves to Death.

\section{References}

Vasil'eva, L.A., 2003. Delaem novosti! [We do the news]. Moscow: Aspekt Press.

Vasil'eva, T.V., Osinskiy, V.G. and Petrov, G.N., 2003. Radyotelevyzyonnaia zhurnalystyka $\mathrm{v}$ systeme profesyonalnykh koordynat [Radio and television journalism in the system of professional coordinates], 2. Sankt Peterburh.

Gagarina, P.A., 2010. Priemy zvukovogo oformleniya teleperadach [Receptions of the sound recording of the telegraph service], [online] Available at: $<$ http://jour.vsu ru/edition/journals/accents/2010/accents_1-2_2010.pdf $>$ [Accessed 21 September 2018].

Dragun, E.M., 2015. Infoteynment kak yavlenie sovremennoy mediakul'tury . [Infocommunity as a phenomenon of modern media culture]. D.Ed. Moscow State University named after MV. Lomonosov

Zvereva, N.V., 2008. Shkola regional'nogo zhurnalista [School of Regional Journalist]. Moscow. 
Zemlyanova, L.M., 1999. Zarubezhnaya kommunikativistika v preddverii informatsionnogo obshchestva. Tolkovyy slovar' terminov i kontseptsiy [Foreign communication science ahead of the information society: an intelligent dictionary of terms and concepts]. Moscow.

Zemskaya E.A., Kitaygorodskaya, M.A. and Rozanova, N.N., 1983. Yazykovaya igra [Language game]. In: Russkaya razgovornaya rech'. Moscow.

Kachkaeva, A.G., 2010. Zhanry i formaty sovremennogo televideniya. Po-sledstviya transformatsii [Genres and formats of modern television. Consequences of transformation]. Vestnik Moskovskogo universiteta. Seriya 10. Zhurnalistika, 10 (44), p.50.

Maydurova, O.F., 2011. Informatsionnye zhanry $v$ regional'nykh novostnykh teleprogrammakh: aktual'nye tendentsii [Information genres in regional news broadcasts: topical trends]. Sankt Peterburh.

Novikova, A.A., 2008. Sovremennye televizionnye zrelishcha: istoki, formy i metody vozdeystviya [Modern TV shows: sources, forms and methods of exposure]. Moscow.

Poznin, V.F., 2004. Osnovy montazha izobrazheniya [Basics of image mounting]. Sankt Peterburh.

Stepanyan, S.K., 2006. Format teleprogrammy kak rynochnyy tovar [TV program format as a market product]. Zhurnalystyka y medyarynok, 4, pp.42-43.

Stilisticheskiy entsiklopedicheskiy slovar' russkogo yazyka, 2018. [online] Available at: $<$ http://stylistics.academic ru/271> [Accessed 21 July 2018].

Kharris, R., 2002. Psikhologiya massovykh kommunikatsiy [Psychology of mass communications]. Sankt Peterburh: PRAYM-EVROZNAK.

Tsvik, V.L., 2000. Vvedenie v zhurnalistiku [Introduction to journalism]. $2^{\text {nd }}$ edn. Moscow: MNEPU.

Postman, N., 1985. Amusing Ourselves to Death.

(C) Цімох Н., 2018

(C) Сорока A., 2018

Стаття надійшла до редакичї 15.10.2018 